\title{
Varkocsfésü és szalu a Balatonudvari-Fövenyes temetőből
}

\author{
'S. PERÉMI ÁGOTA \\ 'Laczkó Dezső Múzeum, H-8200 Veszprém, Török Ignác u. 7. \\ e-mail: peremi@vmmuzeum.hu
}

PERÉMI, Á.: A braid comb and a woodworking adze from the Balatonudvari-Fövenyes cemetery

Abstract: A total of 616 burials were uncovered in 583 graves of the cemetery investigated in 2002, 2009-2010 and 2013. The burial ground is unusual in that the small, narrow valley lying north of Road 71 on the outskirts of Balatonudvari was used during several periods. The site's upper layer contained west to east oriented burials from the tenth-eleventh centuries, underneath which lay north to south oriented burials from the middle and late Avar period. Some grave pits of the Avar period had been repeatedly re-used and we documented several superimposed burials. The two unusual, rare finds presented and discussed here came to light in the cemetery's northern part: a braid comb from Grave 309 and a woodworking adze from Grave 516, both part of the eastern heritage of the Avar population.

Keywords: Avars, braid comb, Maltese cross-shaped buckle, Pápa-type buckle, woodworking adze

\section{Bevezetés}

\section{A temető északi részének kutatástörténete}

A temető kutatástörténetét, az addigi feltárások eredményeit korábbi publikációkban már összefoglaltuk. Ezek a 2002. évi leletmentés és a 2009-2010. évek ásatási eredményeit összegezték. 2013-ban újabb lehetőség nyílt a feltárások folytatására, amelyek során sikerült feltárni a temetőnek a 71-es számú úttól északra eső részét, megtalálni északi határát. A viszonylag szűk völgyet nyugati és keleti oldalról övező, a talaj adottságai miatt temetkezésre alkalmatlan dombok határolják. A kis völgy keleti részén végighúzódó sziklás altalaj miatt sírok már nem kerültek elő, így ezt a temető keleti határának tekinthetjük. A völgy nyugati oldalán ritkás erdő található. Itt csak az erdővel borított domb szélén lehetett feltárni sírokat, de ezek elhelyezkedése alapján úgy tűnik, hogy a temető ebbe az irányba még folytatódik. A fák között néhány helyen meghúzott kisebb próbaárkokban avar és 10-11. századi temetkezéseket találtunk, amelyek igazolják azt a korábbi feltevésünket, hogy a temető nyugati széle az erdős sáv nyugati határán lehet. Ennek feltárása a fák kivágása nélkül nem képzelhető el, ezért egyelőre ebbe az irányba a munkát nem lehetett folytatni. Feltételezésünk szerint maga a temető déli irányban, a 71-es számú út másik oldalán levő völgyben továbbfolytatódik, amely jelenleg magántulajdonban van. Kutatása több nehézségbe ütközik. Így tehát jelenleg a temető északi részének keleti és északi határa tekinthető biztosnak. Az $1400 m^{2}$-nyi területen 583 sírt, pontosabban 616 temetkezést, 2 Árpád-kori objektumot, 1 kutya tetemét rejtő gödröt tártunk fel. A 71-es számú út közelében II. világháborús lövészárkokat találtunk, amelyek több sírt is megbolygattak, vágtak ketté.

\section{Előzmények összefoglalása}

2002 tavaszán, Balatonudvari község nyugati végében, a Fövenyes nevű részen, a 71-es főközlekedési út északi oldalán, egy mélyebb völgyben került elő az a temető, amely korábban ismeretlen volt a szakirodalomban (1.ábra 1.). Az első sírokra szennyvízvezeték fektetése közben bukkantak, amely addig az úttal párhuzamosan haladt, csupán e völgynél vált szükségessé az ároknak az útra merőleges folytatása, északi irányba 30 méter hosszan. Ezt követően derékszögben megtörve, keleti irányba keresztülvágták a völgyet, és a nyomvonalat a dombokon keresztül vezették tovább (1. ábra 2.). A nyomvonal kiásása során szakfelügyeletet láttunk el. A köves, sziklás területen temetkezések vagy más régészeti jelenségek nem kerültek elő.

A 20-24 méter széles kis völgy észak-déli irányú, a Balaton irányába lejt. Feltehetőleg évszázadokkal korábban a Balaton-felvidékre jellemző, a tóba vezető patak (séd) medre lehetett, amely idővel, földdel töltődött fel. Ezt a völgyet vágja ketté a 71-es út. A feltárásokat az úttól északra eső részen folytattuk.

A feltárás első évében a szennyvízvezeték nyomvonalának árka, illetve ennek kisebb kiszélesített részének kutatására volt mód. Ekkor 114 sírt (118 temetkezést) mentettünk meg. Öt év szünet után 2009-2010-ben, illetve 2013-ban nyílt újra lehetőség a munka folytatására (2. ábra). Az eredményeket, egyes sírok feldolgozását több alkalommal tettük közzé. ${ }^{1}$

1 Az első év feltárása, az akkor tett megfigyelések összefoglalása megjelent S. PERÉMI 2003, 279-283. Az első év leletanyagát kiállításon mutattuk be. Ennek leírása a kiállítási katalógusban: S. PerémI 2005, 44-49; S. PeRÉMI 2014, 287-311. 
A balatonudvari temető feltárt területén, ahogy az már a leletmentés és később az ásatások során is dokumentálható volt, az általánostól eltérő temetkezési szokásokat mutatott. Több korszakon keresztül, a közép és a késő avar korban, valamint a kora Árpád-korban is használt temetkezőhely volt.

A terület felső rétegében $\mathrm{Ny}-\mathrm{K}$-i tájolású, 10-11. századi sírok láttak napvilágot. Alattuk ÉNy-DK-i tájolású, közép és késő avar kori, 9. század elejei temetkezések kerültek elő. A 10-11. századi temetkezésekkel nem bolygatták meg a korábbiakat, mi több, nagyon következetesen törekedtek arra, hogy a korábbi sírokban ne tegyenek kárt. ${ }^{2}$ Ebből az időszakból összesen 120 sírt sikerült feltárni.

A 10-11. századi sírok a feltárt terület nyugati felében koncentrálódtak, a terület északi széléhez közeledve ezek a sírok egyre inkább a nyugati, erdős sáv felé húzódtak, az ásatási terület közepén és keleti részén már nem kerültek elő.

E sírok leletanyaga elég szegényes volt, ugyanakkor temetkezési szokások tekintetében nagy változatosságot mutattak (kartartások több változata, kőpakolások). Jellegzetes leletek az egyszerű vagy S-végű fülbevalók, különböző bronz vagy ezüst gyürűk, gyöngyök, vas csat, egy esetben kétélű nyílcsúcs, csörgőgomb, nyakperecek, egy esetben öntött, bronz, korpuszt ábrázoló mellkereszt, amely kis függesztő fül segítségével volt a nyakláncba fúzve.

Sokkal összetettebb volt a közép és késő avar sírok feltárása. Ezek közül az első avar közösség sírjai elsősorban a feltárt terület déli részén és középső sávjában, míg a későbbi avar sírok a temető teljes területén láttak napvilágot.

A feltárt területen megfigyelt sírbolygatások egy részét a területen levő fák vagy bokrok gyökerei, esetleg állattúrások okozták. Újkori bolygatás csak a II. világháborús árkok, valamint a csatorna
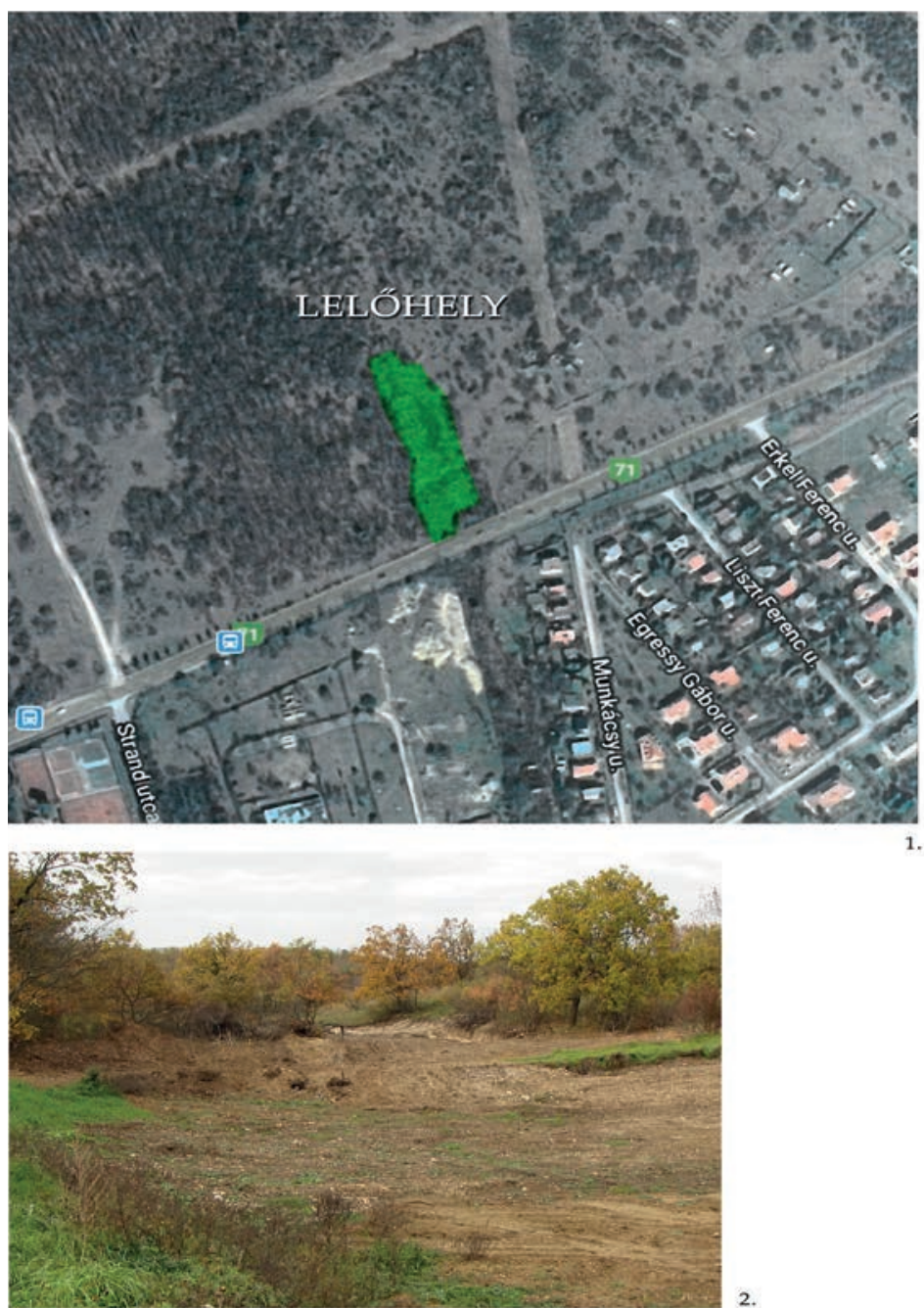

1. ábra. Balatonudvari-Fövenyes lelöhely helyszíne. 1. Google térkép alapján; 2. Fényképfelvétel a lelőhelyröl nyomvonalának kiásása során érte a sírokat. Ugyanakkor éppen az avar korra keltezhető temetőrész esetében több rabolt, bolygatott sír is napvilágot látott, amit elsősorban a korábbi avar kori sírok esetében lehetett megfigyelni. Ezek a rablások egyértelműen a késő avar kori népességhez köthetők, akik nem csak az értékeket vitték el, hanem több alkalommal a már kiásott sírt újra felhasználták: a korábban itt nyugvó csontjait a sír végébe halmozták fel vagy kidobták, és csupán az előkerülő „idegen” vázrészek utalnak arra, hogy a sírgödörbe korábban is temetkeztek. ${ }^{3} \mathrm{~A}$ kifosztás elsősorban az igen mély sírokat kerülte el. Ennek az időszaknak leggazdagabb temetkezései a 195., 531., 536., 110. és 337. fegyvermellékletes sírok, hogy csak néhányat említsünk. Hasonló gazdagságúak a női sírok is.

2 Gyakran saját elhunytjaikat szinte összepréselték, hogy a sír beférjen a korábbi sírok közé. Minden bizonnyal a felszínen még jól látszottak az avar kori sírok hantjai, és ebben a vonatkozásban utalni kell Költő László és Szentpéteri József e témában írt cikkére, amelyben kifejtik: „Egyelöre elégségesnek látszik némely esetben közülük elfogadtatni, hogy a terület folyamatosan temetkezésre szolgált a 9/10. század fordulóján, azaz nem volt időbeli hiátus (törés) a különböző régészeti müveltséggel rendelkező népességek életében." (KöLTő - SzENTPÉTERI 2001, 120-121.) Természetesen ez nem jelenti a két nép egymásba olvadását is, amelynek régészeti bizonyítékai egyelőre még nem állnak rendelkezésünkre.

3 Ennek oka talán az lehetett, hogy a temetkezésre alkalmas terület e kis völgyön kívül nem nagyon volt. A völgyet övező dombokon néhány centi termőréteg alatt köves, sziklás réteg van. A temetőtérképen látható „fehér foltok” is arra utalnak, hogy a területen levő sziklás részeket kénytelenek voltak kihagyni, a sírok szinte körbeveszik ezeket (lásd 2. ábra). 


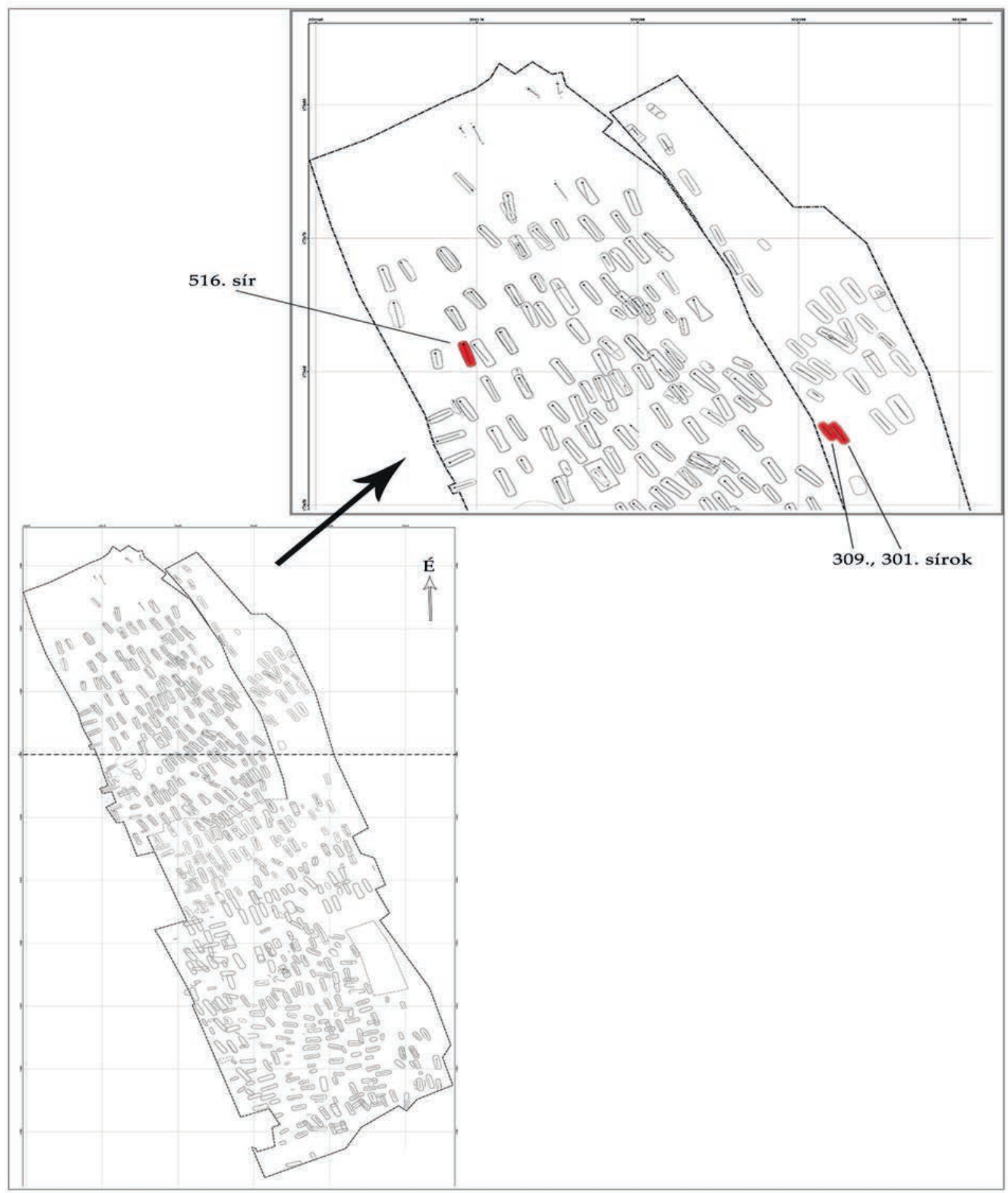


A későbbi avar közösség a korábbi avar sírokra temetkezett rá. A már említett módon a korábban elhunytakat kirabolták, a csontvázakat szétdobálták, összetörték. Mellettük, az avar korban szinte egyedülálló módon, gyakran egy sírgödörbe több rétegben egymásra temetett, a leletanyag alapján avar korra (közép, felette nem ritkán két, sőt három késő avar kori) keltezhető temetkezés volt, de az egy sírgödörbe, közel azonos időben eltemetett két vagy három elhunyt sem volt ritka (felnőttek vagy felnőtt-gyerek vázak). Az esetek nagy részében a késő avar sírok nem bolygatták meg a késői közösség korábban elhunyt tagjának sírját. A különlegesebb temetkezési szokások között említhetjük még az ellenkezőleg tájolt (D-É-i), vagy az egy sírba É-D-i, mellette D-É-i tájolású közös temetkezést, vagy a zsugorított helyzetű csontvázakat.

A késő avar kori férfi sírokban öntött, griffes-indás vagy hármas csoportosítású övgarnitúrák, a veretes övek mellett nyílcsúcsok, íjcsontok, hosszúkések, bogozók, tarsolyzárak is napvilágot láttak. Ritka leletnek számít a 454. sír öntött veretekkel díszített övre függesztett csont sótartója. A többi sírban vas kések, karikák, csatok, tűzszerszámok kerültek elő leggyakrabban. A női sírok szokásos mellékletei mellett (fülbevalók, gyöngynyakláncok, gyűrük, karperecek, tarsolykorongok, munkaeszközök), három sírból mellboglárok, egy esetben ólom csüngők is napvilágot láttak. Az avar kori temetkezési szokásoknak megfelelően sok állatcsont, tojás, edénymelléklet, köztük két sárga kiöntőcsöves edény és egy esetben tál került elő. Természetesen a fentiek csak nagyvonalakban foglalják össze a temetkezési szokásokat, leletanyagot, kis ízelítőt adva erről a nem szokványos, különleges temetőről.

Összefoglalva: A Balatonudvari-fövenyesi temető a Kárpát-medencei avar és 10-11. századi emlékanyagban különleges helyet foglal el, amely a két eltérő etnikumú, valamint a több rétegú közép- és késő avar temetkezéseknek köszönhető.

Ez alkalommal két olyan sír leleteit mutatjuk be, amelyek a szakirodalomban is ritkán bukkannak fel.

\section{Varkocsfésü}

A kis varkocsfésű a 309. sírból került elő, amely a feltárt terület felső, északi harmadában, a temető keleti szélének közelében helyezkedett el. Közvetlen közelében, részben rátemetve a sír keleti oldalán került elő a 301. sír, de nem bolygatta az alatta levőt (2., 3. ábra 1.). ${ }^{4}$

Sírleírás: É-D-i tájolású $\left(317^{\circ}\right)$, hanyatt fektetett, nyújtott helyzetű fiatal férfi sírja. A csontok rossz megtartásúak voltak. A kissé töredékes koponya a váz felé billent. Hiányoztak a jobb karcsontok. ${ }^{5}$ Bal karcsontok szorosan a váz mellett, alkarcsontok behajlítva, a töredékes medencecsonton. Sírmélység 72 centiméter (4. ábra). ${ }^{6}$ Mellékletek:

Téglalap átmetszetű vashuzalból hajlított, téglalap alakú csat tüskével a jobb medencecsont felső ívénél, h: $3,1 \mathrm{~cm}, \mathrm{sz}: 2,7 \mathrm{~cm}$. (4. ábra 1., 5. ábra 2.)

Erősen töredékes, kisebb, egyenes hátú, egy élü, nyéltüskés vas kés a jobb combcsont mellett, pengéjén fa nyomokkal, h: $6 \mathrm{~cm}$. (4. ábra 2., 5. ábra 3.)

Erősen töredékes, három élú nyílcsúcs a bal combcsont belső oldalán, h: 4,6 cm. (4. ábra 3., 5. ábra 1.)

Tarsoly szerves maradványai a jobb medencecsont mellett (3. ábra 2.). Ebben:

háromszög alakú, lapos csontból készült varkocsfésű, 12 ép, hegyesedő végű foggal. Két fog hiányzik az egyik szélén. A fésű fogója tömör, szélei keskenyítettek, h: $7 \mathrm{~cm}, \mathrm{sz:}: 2,2 \mathrm{~cm}$. (4. ábra 4c., 5. ábra 4c.) egy csomóba összekorrodált, ismeretlen rendeltetésủ vas tárgy. A korrózió csomóban egy négyszögletes(?) vaslemez részletei látszanak, egyik sarkán lyukkal, h: 3,6 cm, sz: 2,4 cm. (4. ábra 4d., 5. ábra 4d.) apró, barnás színű kova, méretek: 2,1×1,4 cm. (4. ábra 4c., 5. ábra 4e.)

állatfejes díszű szíjbújtatós bizánci bronz csat, töredékes csatkarikával, tüske hiányzik. A rögzítésre szolgáló két tag is töredékes, h: 3,8 cm, sz: 4-1,6 cm. (4. ábra 4b., 5. ábra 4a.)

bronzból öntött, kisebb, máltai kereszt alakú csat. Karikája hiányos, a hátoldalán levő rögzítő fül törött, h: $3,2 \mathrm{~cm}$. (4. ábra 4a.,5. ábra 4b.)

Kisállat (tyúk?) csontok a bal combcsont mellett és felett (kép nélkül).

4 A felső, 301. sír É-D-i tájolású (318) volt, amelyben hanyatt fektetett, nyújtott helyzetű felnőtt nyugodott. A töredékes koponya kissé a jobb oldalra és a váz felé billent. Karcsontok szorosan a váz mellett, jobb alkarcsontok a medencén („felhúzott vállak”). Bal medencecsont élén. A csontváz helyzete arra utal, hogy az elhunytat valamibe szorosan betekerték. Sírmélység 31 centiméter. Melléklet csupán a két combcsont között, ezek felső végénél előkerült szarvasmarha csont volt.

5 A területen a feltárás előtt több vadon nőtt bokor, kisebb-nagyobb fa állt. Nagy valószínűséggel a gyökerek bolygatták meg a csontvázat.

6 A területen átlagban 60 centiméter, gyökerekkel sűrűn átszőtt humuszréteget dózeroltattunk le. A sírleírásoknál jelzett mélység a sír jelentkezésétől számított mélységet jelzi. 


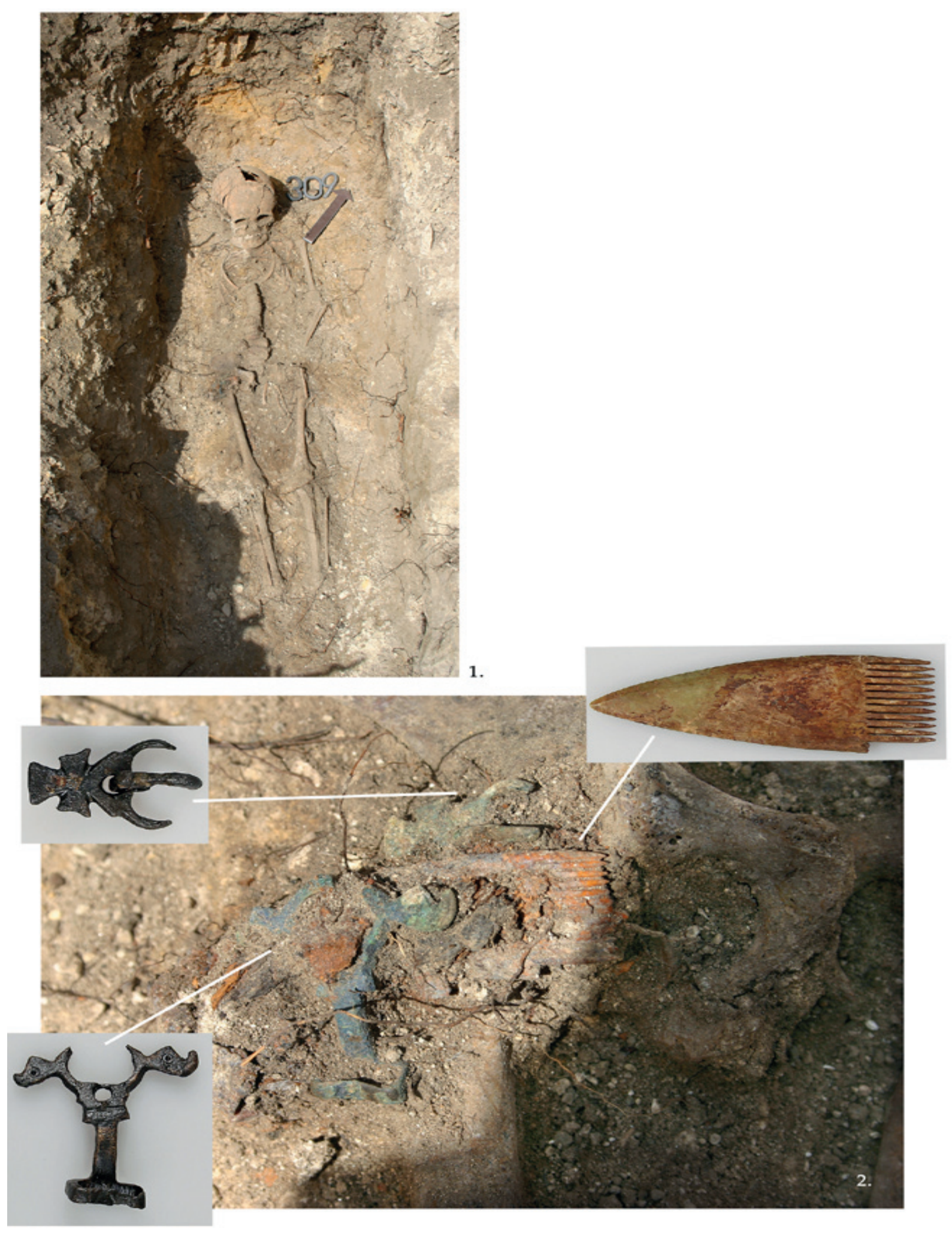

3. ábra. 1. A 309. sír fotója; 2. A 309. sír tarsolyának fotója a leletekkel 

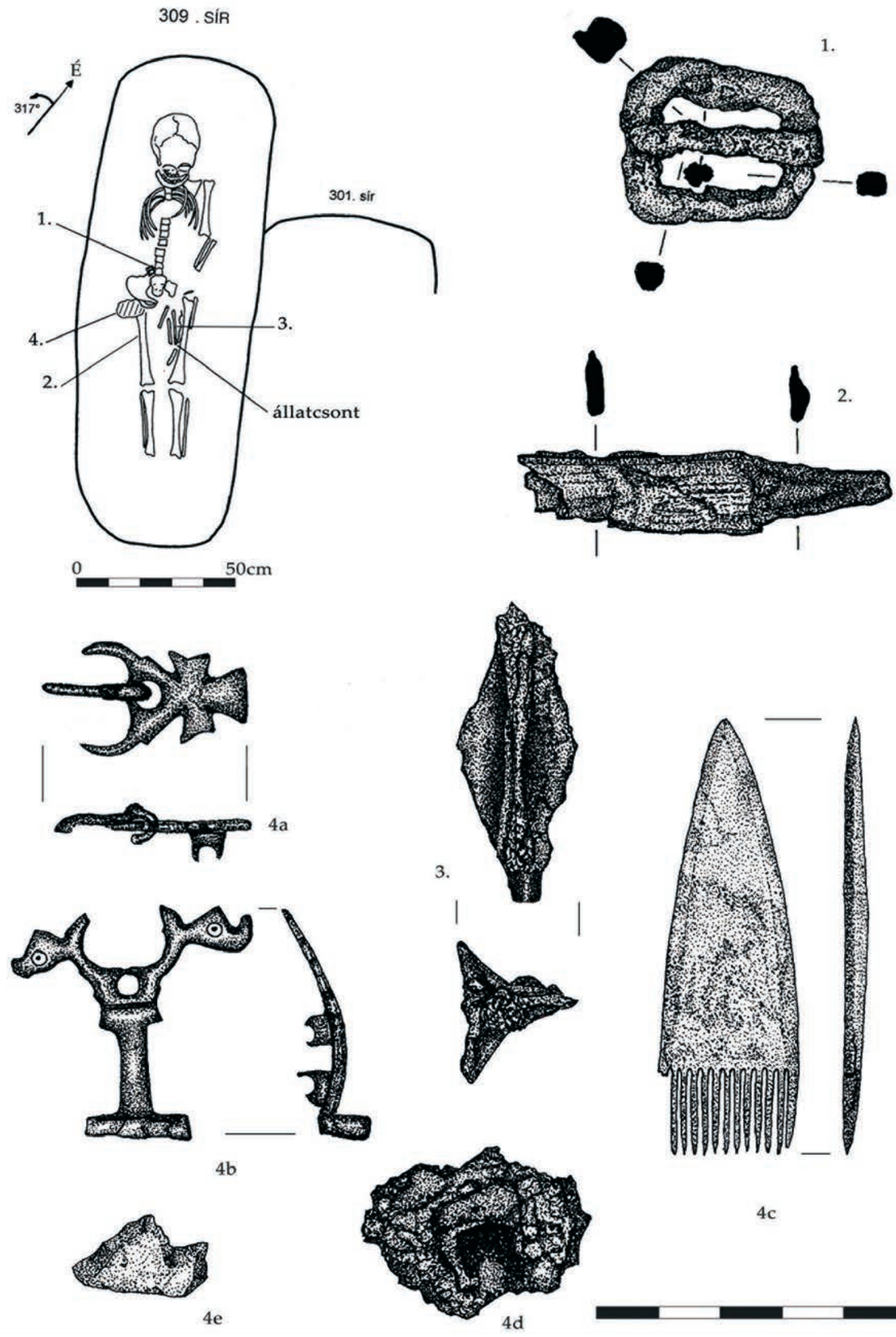

$4 \mathrm{e}$

4. ábra. 309. sír rajza és leletanyaga (1-4e) 

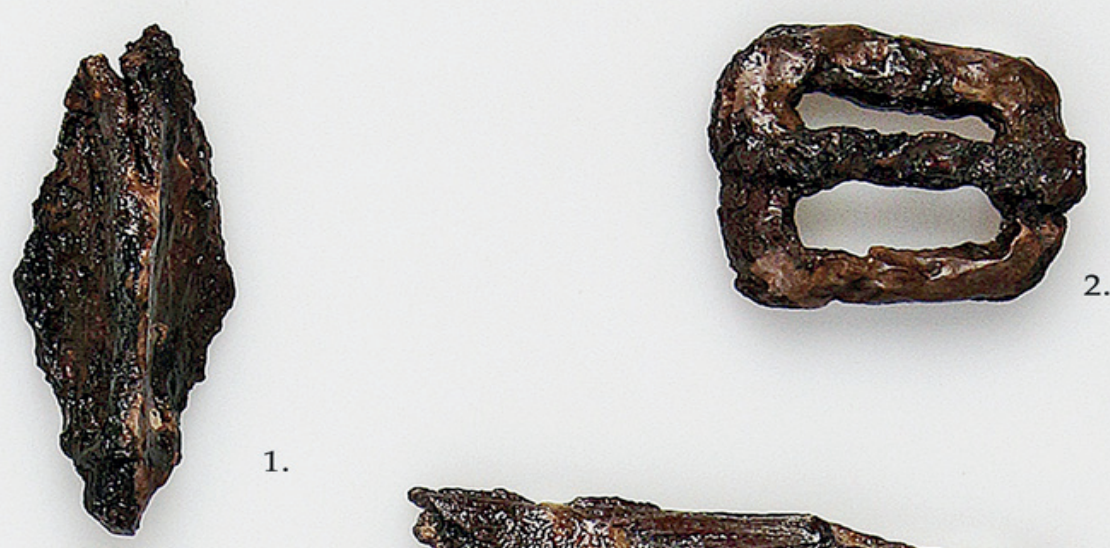

1.
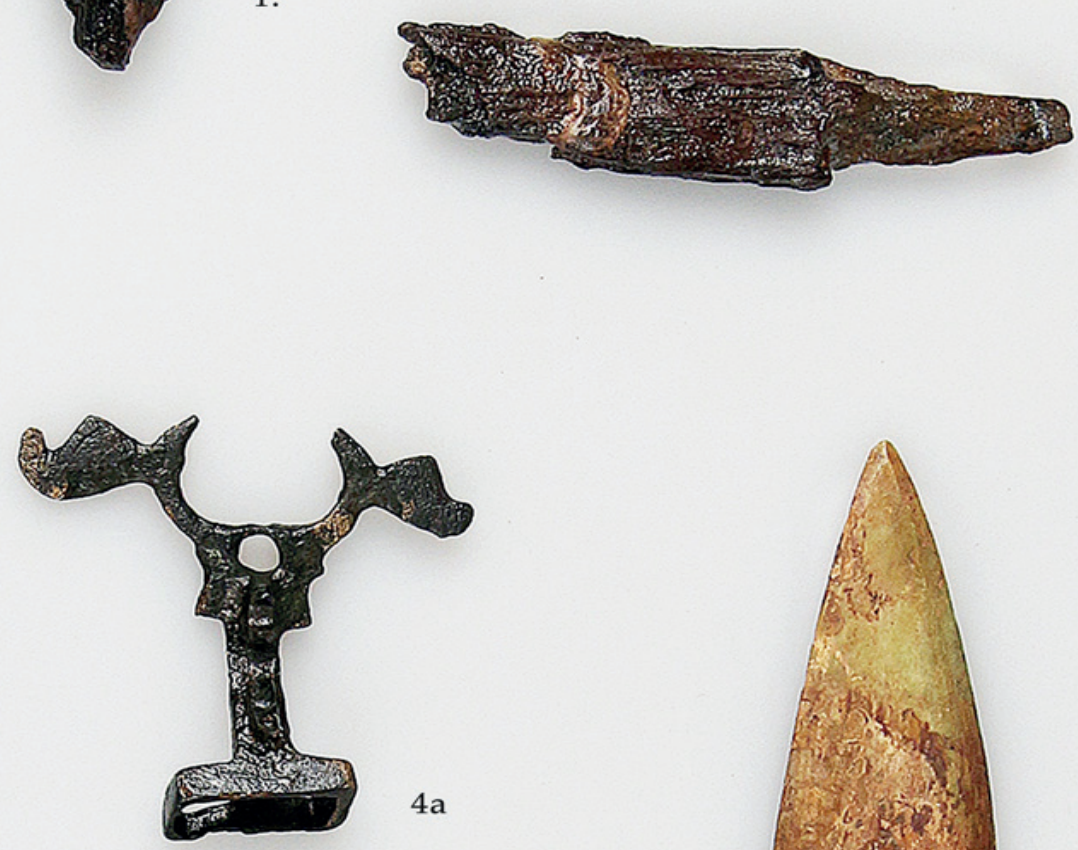

3.
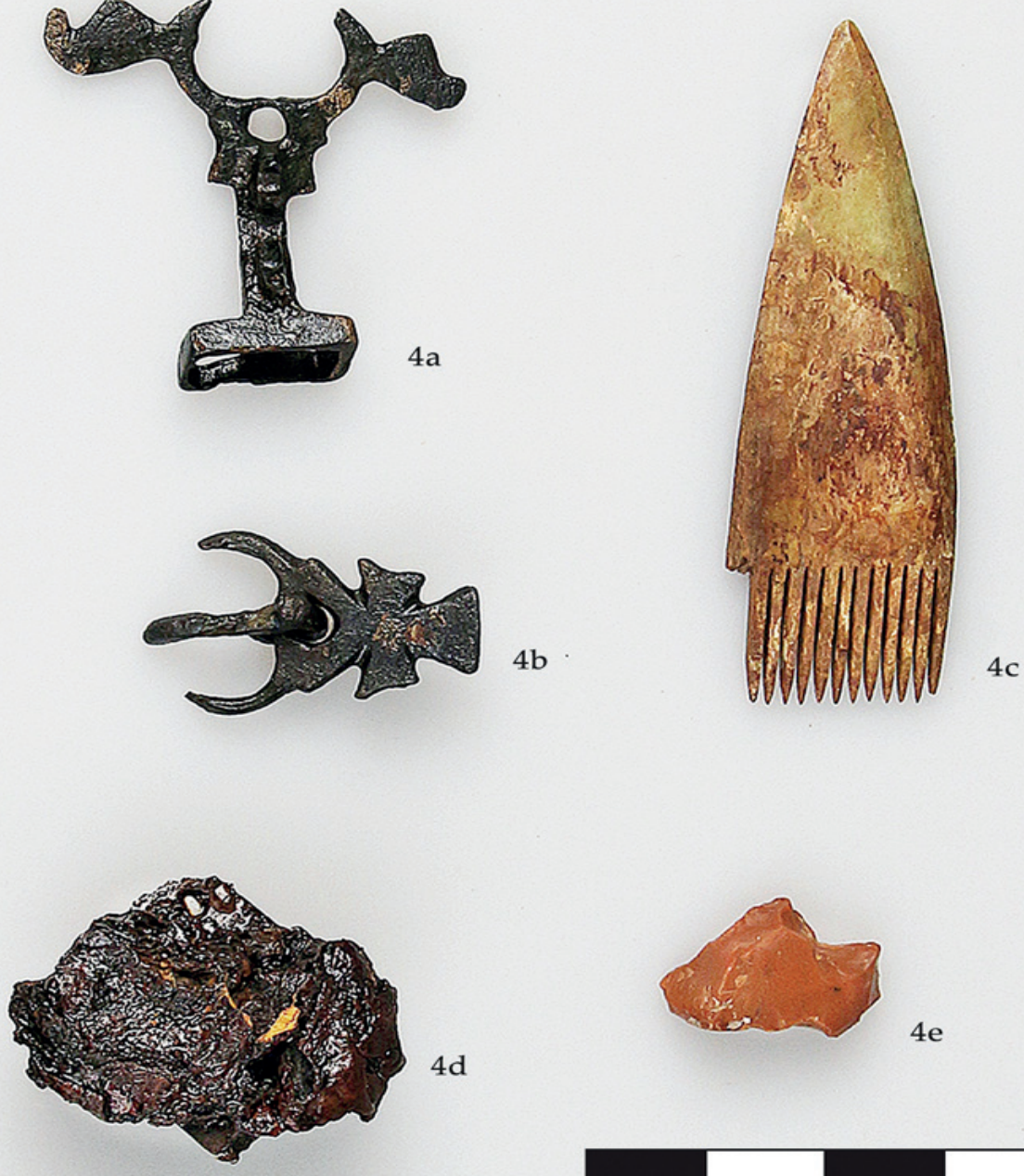

5. ábra. 309. sír leletei 


\section{A sír anyagának elemzése}

A fiatal férfi sírjának mellékletei egy vas csattal összekapcsolt öv, és az erre erősített késtartó tok, tarsoly és a benne található tárgyak voltak.

A nagyjából 1 centiméter széles övet összefogó téglalap alakú csat általános viseleti elem, különösebben nem korhatározó.

Az erősen töredékes, kisméretű kés szintén gyakori tárgy a sírokban. Általános viseleti helyén, a jobb combcsont mellett került elő. A kés pengéjén megmaradt fa nyomok alapján, fa tokban őrizte tulajdonosa, az övre erősítve.

Szintén töredékes állapotban került elő a bal combcsont belső oldalán egy három élű vas nyílcsúcs, hegyével felfelé. Az íjászat egyéb felszerelésének nem volt nyoma. Általános, különösebben szintén nem korhatározó típus.

A sírba helyezett állatcsont (nagy valószínűséggel tyúkmelléklet) az elhunyt és az őt eltemető közösség, a halálon túli élet folytatásába vetett hitét jelzi. Helye a sírban szintén nem tér el a hagyományos szokásoktól.

A sír leletei között a legérdekesebbek, bizonyos értelemben különlegesek, a tarsolyban őrzött kis tárgyak. A kovakő és gyaníthatóan csiholó, pontosabban a korrózió miatt közelebbről meg nem határozható kis vas lemez darabbal együtt a tűzgyújtás kellékei voltak. Ezek mellett szintén a tarsolyban őrzött állatfejes díszű szíjbújtatós, valamint kisebb máltai kereszt alakú bizánci bronz csat már használaton kívüli darabok lehettek, minden bizonnyal értékes tárgyként őrizte tulajdonosa. Mindkét bronz csat karikája és a rögzítő fülek töredékesek voltak.

Az állatfejes díszű tarsolycsat (4. ábra 4b., 5. ábra 4a.) az ún. pápai típusba tartozik. A bizánci eredetű csatok között a tarsolycsatok viszonylag ritka mellékletek, amelyek tarsolyok, kisebb táskák, esetleg késtokok szíjazatához tartoztak, gyakran kisebb szíjvéggel együtt kerülnek elő.7 A bronzból egybeöntött, jellegzetes formájú, gyakran pont-kördíszes csatokat a hátoldalukon levő kis trapéz- vagy négyzet alakú fülek segítségével erősítették fel. ${ }^{8}$

A 6. század második felétől megjelenő csatokkal és ezen belül az állatfejes, állatalakos csatokkal részletesebben Syna Uenze foglalkozott, típusokba sorolva ezeket, többek közt meghatározta a pápai típusú csatok körét is. ${ }^{9}$ Jellemzőjük a csatkeret két oldalán levő, kifelé néző madárfejek, a szemek jelzésére pont-kör díszítéssel. Gyakran a csat felületét is pont-körök díszítik. Nagy valószínúséggel a Salona-Histria típusú csatok továbbfejlődött változatai. ${ }^{10}$ Kialakulásukat Uenze a 7. század első felére, közepére teszi. ${ }^{11}$

Garam Éva a 7. század első harmadának végére keltezi e csatokat. ${ }^{12}$ A kutató a típusba avar környezetből 6 példányt, ${ }^{13}$ Kiss Gábor a felfelé hajló stilizált fejjel díszítettek közé 9 darabot sorolt. ${ }^{14}$ Madgearu a típus teljes felgyűjtése során 28 példányt írt le. ${ }^{15}$

Elterjedését tekintve a Kárpát-medencében elsősorban dunántúli (6), és két esetben tiszántúli lelőhelyekről láttak napvilágot. A Madgearu által felgyűjtött darabok ezen a képen nem változtatnak, ugyanakkor megállapítja, hogy az avar kaganátus területén kívül elökerült összes többi csat a Fekete-tenger közeli lelőhelyekről származik, ${ }^{16}$ olyan területekről, amelyek valamilyen módon kapcsolatban lehettek az avarsággal. Nagy valószínűséggel bizánci műhelyekben, kifejezetten a „,barbárok” számára készített darabokról lehet szó. ${ }^{17}$

Mindenesetre a balatonudvari kis töredékes csat eggyel növelte a Dunántúlon elökerült darabok számát, még ha ez már sérült példányként a 7. század második felében, vége felé kerülhetett a sírba.

A 309. sírból előkerült tarsolyban a másik, szintén bizánci eredetű csat egy kis méretű, máltai kereszt alakú bronz csat volt (4. ábra 4a., 5. ábra 4b.). A kárpát-medencei leletanyag áttekintése után az udvari darabon kívül csupán a Zamárdi-Réti földek temető 748. sírjából került elő hasonló darab (6. ábra 2., 4.). ${ }^{18} \mathrm{~A}$ két csat méretre, kivitelre szinte teljesen azonos, azzal a különbséggel, hogy az udvari darabnak a tüskéje is meg maradt (6. ábra 1, 3. és 2., 4.). ${ }^{19}$ Ugyanakkor a zamárdi sírban több, keletező értékű melléklet is napvilágot látott: ezüst, felhúzott

7 Garam 2001, 108.

8 Schulze-Dörrlamm 2002, 146-228, 246-250.

9 UenZe 1966, 149-152.

10 Uenze 1966, 165-166; Garam 2001, 109-111.

11 Uenze 1966, 152.

12 Garam 2001, 111.

13 Garam 2001, 11.

14 Kiss 1998, 472, 7. kép

15 Madgearu 2003, 170-171.

16 Dobrudja, Krím, Kis-Ázsia, kivéve egy iráni darabot, lásd elterjedési térkép Fig. 1.

17 Madgearu 2003, 171-172.

18 BÁRDOS - GARAM 2009, 104-105, Taf. 93/12, Taf. 193. Korábban a publikált szakirodalomban ennek nem volt nyoma. Lásd OTKA ZÁRó JeLENTÉs 61. lábjegyzet.

19 A ritka csattípus újabb bizonyítékkal szolgál arra, hogy a zamárdi közösség tagjai kapcsolatban lehettek a Balaton északi partján élő avarsággal, vagy egyes csoportjai telepedtek át. Lásd BAKAY 1973, 5-86; S. PERÉMI 2003, 271-294. 
lemezgömb-díszes fülbevalópár, kb. 100 darab zömében szemes gyöngyböl álló nyaklánc, bronz karperecek, bronz csat, agyag orsógomb, több római kori tárgy (fibula, kulcs, érem stb.), vas kések - egyik volutás végű -, egyéb vastöredékek, amelyek a temetkezést a 7. század közepére, esetleg második felére keltezik. A máltai kereszt alakú csatot a tulajdonosa, minden bizonnyal a többi római kori darabbal együtt, értékes alapanyagként(?) őrizte meg.

A bizánci eredetủ máltai kereszt alakú csatok elterjedésével Vladimír Varsik foglalkozott korábban. A kis méretű csatot a mediterrán-adriai csoportba sorolta. ${ }^{20} \mathrm{~A}$ kereszt alakú csatok, véleménye szerint, a keresztény hitre utalnak, felületüket gyakran pont-kör mintával díszítik. A csattípus különösen nagyobb városokban bukkan fel, mint Konstantinápoly (Taf. III. 12.), Athén. A párhuzamok alapján a kereszt alakú csatokat a 6-7. század fordulójára, 7. századra keltezi, mindazok ellenére, hogy krími feltárások során sokkal későbbi, V. Leo (813-820) érméjével együtt is napvilágot láttak. Ezt a korábban divatos ékszer továbbviselésével magyarázza. ${ }^{21}$

Nagyobb tanulmányt szentelt a bizánci csatok feldolgozásának Schulze-Dörrlamm, aki sokkal több részlet figyelembevételével csoportosítja az egyes csatokat. ${ }^{22} \mathrm{~A}$ kis méretű, máltai kereszt alakú csatok közül összesen tizennyolc darabot mutat be, amelyeket a D22 típusba sorolt. ${ }^{23} \mathrm{~A}$ balatonudvari és a zánkai daraboknál mutatkozó nagy hasonlóság jellemzi az általa gyűjtött példányokat is, mintha egymás párjai lennének. Ennek alapján úgy véli, hogy akár lábbeli vagy tarsolyt záró csatok is lehettek, illetve a valamivel nagyobb, pont-kör díszes példányokat övcsatként is viselhették. Véleménye szerint a csatok gyártása, divatja a 7. század első felében kezdődik és még a század második felében is tart. ${ }^{24}$ Gyüjtése alapján ezek a kis méretű csatok elsősorban a Krím-félszigeten, ${ }^{25}$ Görögországban, a görög szigeteken, Szicíliában és Itáliában fordulnak elő. Egy példány a Balbi Kripta bronzöntödei műhelyéből került elő, minden bizonnyal itt is készült.

A Schulze-Dörrlamm által megállapítottak megerősítik azt a véleményt, hogy az udvari és minden bizonnyal a zánkai darabok is, mint törött, használaton kívüli darabok a 7. század második felében kerülhettek sírba.

A tarsolyban talált, bizánci eredetű csatok típusukat tekintve viszonylag ritkák a hazai avar emlékanyagban. Eredetileg mindkettő tarsolyzár lehetett, készítésük és minden bizonnyal használatuk az avar kor korai időszakára tehető. A sérült, használaton kívüli példányok sírba kerüléskor már csak tarsolyban őrzött darabok voltak. Kérdéses, hogy azonos funkciójú, azonos időszakra keltezhető csatok hogyan kerülhettek későbbi tulajdonosukhoz. Elképzelhető, hogy a balatonudvari közösség egy korábbi avar közösség leszármazottjaként telepedett le a Balaton vidékére, és nyitotta meg temetőjét. Az udvari 309. sír a temető közép avar kori sírjai közé sorolható. ${ }^{26}$

Egy korábbi avar közösséggel való kapcsolatra utalhat a sírból előkerült, ritkaságszámba menő, szintén a tarsolyban őrzött csont varkocsfésü (4. ábra 4c., 5. ábra 4c.). A magyarországi avar kori emlékanyagban ez a hatodik darab és a negyedik lelőhely. Szemben a púpos hátú, egy és két oldalas csont fésűkkel, a varkocsfésűk száma igen csekély, az udvari példányon kívül újabb, további darabokról egyelőre nincs tudomásunk.

A fésútípussal a legbehatóbban Csallány Dezső foglalkozott elsőként a deszki darab kapcsán. ${ }^{27}$ Végeredményben ő határozta meg a melléklet funkcióját. ${ }^{28} \mathrm{Az}$ alattyáni temető három fésűje kapcsán Kovrig llona - Csallány nyomán - foglalkozott a leletekkel. ${ }^{29}$ Gyakorlatilag azóta, új lelet híján, csupán egyes összefoglalásokban említették a varkocsfésűk kérdését. ${ }^{30}$

20 VARSIK 1992, 84-85, 93, Taf. III. 11. sz.

21 VARSIK 1992, 85.

22 Schulze-Dörrlamm 2002, 193-208. Elterjedési térkép: Abb. 71. Újabb darabok: Schulze-Dörrlamm 2009, 400-401, 613, 614. számon, D 22. típusba tartozó, ismeretlen lelőhelyűek.

23 További ismertetések, összefoglalások: EscheR 2014, 305-308. FIG. 3., 2.3., 5.; ENTwISTLE 2010, 22., 12. számú csat, pont-kör díszes, D 22. típusba sorolja.

24 A Krím-félszigeten feltárt temetkezések alapján (Lucsisztoje, Eski Kermen, Kercs; Sook-Su) Ajbabin a 7. század második felére keltezi a csattípust. АйБАБин 1999, Табл. XXIX. 30, Табл. XXX. 25, 44, 45.

25 Az internetes oldalakon gyakran ajánlanak vásárlásra a Krím vidékén talált(?), szerzett(!) bizánci eredetủ leleteket, többek közt kereszt alakú csatokat is, gyakran párban, alátámasztva az eredetükről tudottakat, illetve feltételezett lábbeli díszítő funkciójukat.

26 A temető feltárt sírjainak teljes feldolgozásáig ennél pontosabb keltezésre nem vállalkozhatunk.

27 CSALLÁny 1943, 3-8.

28 A Kamennaja bábák ábrázolása alapján a haj fésülésére használt eszközként határozta meg. Ezzel szemben Erdélyi István a mongoloid embertípushoz köthető szakállfésűnek vélte. ERDÉLYI 1982, 201.

29 KOVRIG 1963, 139

30 Kürti 1983a, 36. V, t. 6; BAlogh 2016, 61; Bővebben Mesterházy 2012, 815-816; Balogh 2013, 282. 
Az alábbi táblázatban összefoglaltuk a varkocsfésűket tartalmazó sírokat (7. ábra):

\begin{tabular}{|c|c|c|c|c|c|c|}
\hline & Lelőhely & $\begin{array}{l}\text { Csontváz } \\
\text { neme }\end{array}$ & $\begin{array}{c}\text { Fésü leírása, helye a sír- } \\
\text { ban }\end{array}$ & Keltezés & Ábra & Irodalom \\
\hline 1. & $\begin{array}{l}\text { Szabadka- } \\
\text { Mácskovics tég- } \\
\text { lagyár/Subotica } \\
\text { ciglana } \\
\text { Macskovics }\end{array}$ & férfi & $\begin{array}{l}\text { Csúcsban végződő, tömör, } \\
14 \text { db fésűfog, h: } 6 \mathrm{~cm} ; \text { sz: } \\
2 \mathrm{~cm}\end{array}$ & $\begin{array}{l}\text { 7. század } \\
\text { első fele }\end{array}$ & 7. ábra 1. & $\begin{array}{c}\text { BiBó-BIGE 1901, 431-432; } \\
\text { BiBó-BIGE 1902, 408-410; } \\
\text { HAMPEL 1905, III. 494-495; } \\
\text { II. 839-840; } \\
\text { CSALLÁNY 1943, 3-8. }\end{array}$ \\
\hline 2. & Deszk G. 2. sír & férfi & $\begin{array}{l}\text { Csúcsban végződő, átfúrt, } \\
12 \mathrm{db} \text { fésűfog. } \\
\text { Két combcsont között, } \\
\text { tarsoly mellett, h: } 9,8 \mathrm{~cm} \text {; } \\
\text { sz: } 3,1 \mathrm{~cm} \text {. }\end{array}$ & $\begin{array}{l}\text { 600-620, } \\
\text { kora avar }\end{array}$ & 7. ábra 2. & CsalLÁNy $1943,3-8$. \\
\hline 3. & $\begin{array}{l}\text { Alattyán-Tulát } \\
\text { 50. sír }\end{array}$ & férfi & $\begin{array}{l}\text { Csúcsban végződő, tömör, } \\
\text { h: } 10,6 \mathrm{~cm} \\
\text { sz: } 2,8 \mathrm{~cm}\end{array}$ & $\begin{array}{l}\text { kora avar } \\
\text { kor }\end{array}$ & 7. ábra 3. & $\begin{array}{l}\text { KovRIG 1963, 13, Taf. 3:53.; XLVI. } \\
\text { 10-14. }\end{array}$ \\
\hline 4. & $\begin{array}{l}\text { Alattyán-Tulát } \\
\text { 190. sír }\end{array}$ & férfi & $\begin{array}{l}\text { Félkörös végű, átfúrt, } 15 \text { db } \\
\text { fésűfog, jobb karcsontok } \\
\text { környéke, h: } 4,8 \text { cm, sz: 3,2 } \\
\mathrm{cm}\end{array}$ & $\begin{array}{l}\text { középső } \\
\text { avar kor }\end{array}$ & 7. ábra 4. & KovRIG 1963, 24, Taf. 16:15 \\
\hline 5. & $\begin{array}{l}\text { Alattyán-Tulát } \\
\text { 564. sír }\end{array}$ & férfi & $\begin{array}{l}\text { Félkörös végű, átfúrt, 19- } \\
20 \text { db fésűfog, sír közepe } \\
\text { táján, h: } 8,6 \mathrm{~cm}, \mathrm{sz:} 4,4 \mathrm{~cm}\end{array}$ & $\begin{array}{l}\text { középső } \\
\text { avar kor }\end{array}$ & 7. ábra 5. & KovRIG 1963, 50, Taf. 36:46. \\
\hline 6. & \begin{tabular}{|l|} 
Balatonudvari- \\
Fövenyes 309. \\
sír
\end{tabular} & fiatal férfi & $\begin{array}{l}\text { Csúcsban végződő, tömör, } \\
12 \mathrm{db} \text { fésűfog, jobb me- } \\
\text { dencecsont mellett, h: } 7 \\
\mathrm{~cm}, \mathrm{sz:} 2,2 \mathrm{~cm}\end{array}$ & $\begin{array}{l}\text { középső } \\
\text { avar kor }\end{array}$ & 7. ábra 6. & \\
\hline
\end{tabular}

1. táblázat. Avar kori varkocsfésük a Kárpát-medencében

A táblázat adatai alapján jól látszik, hogy a fésűk kizárólag férfiak sírjából kerültek elő, általában a jobb oldalon. Az átfúrt darabok esetében feltételezhető, hogy az övre voltak függesztve, míg a tömör fogójúakat tulajdonosa a tarsolyban őrizte. Csallány Dezső - Fehér Géza nyomán ${ }^{31}$-, a „Kamennaja baba” szobrokon látható ábrázolások alapján is erre következtetett, vagyis az átfúrt végű fésűket az övre erősítve, a jobb oldalon viselték, együtt a késtartó tokkal, tarsollyal (8. ábra). ${ }^{32}$

A balatonudvari fésút, tulajdonosa a tarsolyban őrizte, igen jó állapotban maradt meg, a fésűfogak szinte sértetlenek. Felületén a mellette levő bronz csatok zöldes elszíneződése látszik.

31 FEHÉR 1931, 86-102, 97. és 98. kép

32 Csallány 1943, 5, I. tábla 5. A szabadkai darab publikálója, Bibó-Bige György, akár csak a sír többi csontleletét, tévesen, takácseszközöknek vélte. A fésű, véleménye szerint a fonal fésülésére szolgált. BıBó-BıGE 1902, 409-410.

A Kőfaragványok (Kamennaja Bábá, Каменные изваяния) kutatásának nagy szakirodalma van. (A 6. századi Altáj-vidéki türkök hagyatékában megjelenő szobroktól a 11-13. századra keltezett dél-oroszországi polovec (kunok) szoborábrázolásokig. Lásd többek közt Mogilnyikov 1981, 42, puc. 22-23; Jevtyuhova 1952; Fjodorov-Davidov 1966; Pletneva 1981, 213-222, puc. 87-89.). Az ezeken megfigyelhető övre erősítve viselt fegyverek, használati tárgyak ábrázolása az avar viseleti szokások rekonstruálásához is felhasználható. A fésűk kapcsán a legtöbb és egyúttal leggazdagabb ábrázolás a kunokhoz köthető szobrokon figyelhető meg. Fjodorov-Davidov részletesen elemezte az ábrázolt fésűk típusait. 4 típust különített el: 1. félköríves, alján kis vonalak utalnak a fésű fogaira; 2 . trapéz alakú, fésűfogakra utaló vonalkákkal az alján; 3. téglalap alakú, két oldalán fésű fog ábrázolással; 4. kettős trapéz alakú, két oldalán fésűfog ábrázolással. Jelen esetben ezek közül az első két változat fontos számunkra. Ennek kapcsán lásd a 8. ábra 1. első típus; 8. ábra 2. második típus). 

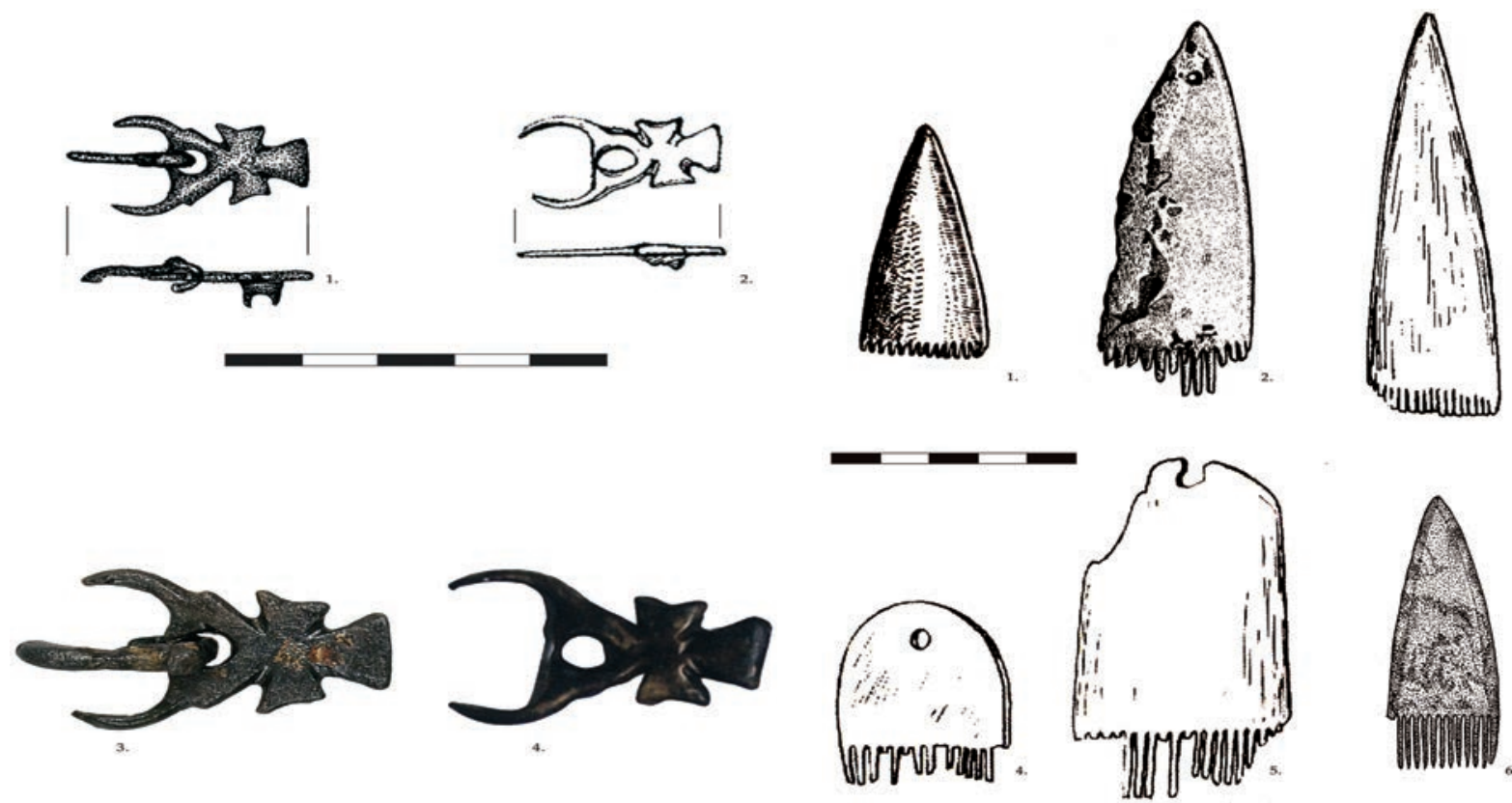

6. ábra. Máltai kereszt alakú csatok. 1, 3. 309. sír lelete; 2,

7. ábra. Varkocsfésűk. 1. Szabadka-Mácskovics tég4. 748. sír lelete Zamárdi-Réti földek lelöhelyről (BÁRDOS GARAM 2009 nyomán) lagyár/Subotica ciglana Macskovics; 2. Deszk G. 2. sír; 3. Alattyán-Tulát 50. sír; 4. Alattyán-Tulát 190. sír; 5. Alattyán-Tulát 564. sír; 6. Balatonudvari-Fövenyes 309. sír
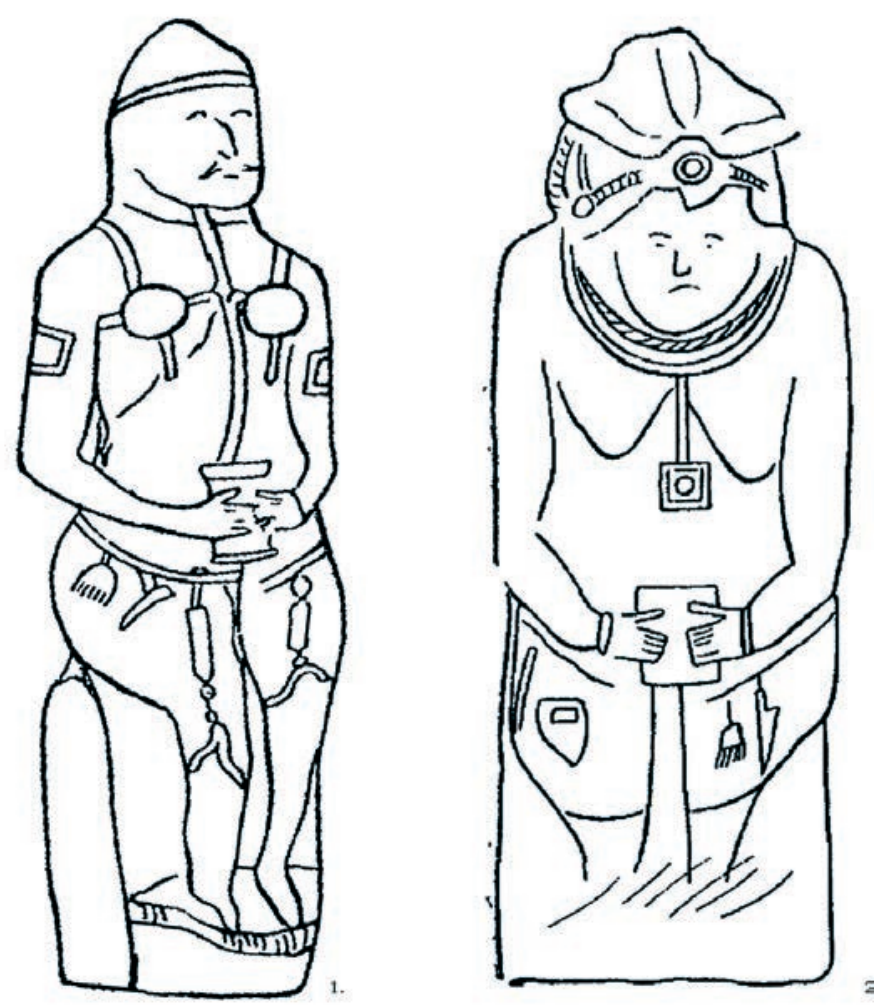

8. ábra. 1-2. Kamennaja bábák (FJoDoRov-DAVIDOV 1966. nyomán) 
Az avarok megjelenése előtt ez a fésűtípus nem ismert a Kárpát-medencében. A kora avar korban jelent meg, ${ }^{33}$ de később is használatban lehetett. A csekély adatok alapján úgy tűnik, hogy a korai példányok csúcsos, háromszög alakúak voltak, a valamivel későbbiek félkörös záródásúak, kissé nagyobb méretűek.

Balogh Csilla a legkorábbi, a 7. század első évtizedeire keltezhető fázisba sorolt köznépi temetőkre jellemző ázsiai eredetű tárgyak között említi a varkocsfésűket. Feltűnésüket a Duna-Tisza közén ekkor megjelenő kis közösséghez köti, amely a Kárpát-medencébe kívülről költözött e területre. ${ }^{34}$

A balatonudvari darab formáját tekintve a korai változathoz áll közel, és nagy valószínūséggel a kora avar kor idején készült. Ugyanakkor, ahogy azt a töredékes bizánci eredetű csatok esetében is megállapíthattuk, sírba kerülése már a közép avar korra tehető. Kérdés, hogy tulajdonosa csupán őrizte vagy még használatban volt?

A csontból készült fésűk különböző típusai a korai időszakban még viszonylag gyakori mellékletek. A kétsoros vagy púpos hátú fésűk a közép avar korban csak elvétve kerülnek elő, míg a késő avar korban a fésűmelléklet szinte teljesen eltűnik a sírba helyezett mellékletek közül. Ennek oka talán kapcsolatban lehet a viselet, ezen belül a hajviselet változásával.

Az avar férfiak hajviseletéről egyébként is csak nagyon keveset tudunk, pontosabban a varkocsszorítók kapcsán fogalmazódtak meg különböző vélemények. A fém hajfonatdíszek a kutatás szerint a 7. század utolsó harmadában jelentek meg a Kárpát-medencében, és a 8. század végéig követhetők nyomon. Előzmény nélkül jelentek meg, és minden bizonnyal egy új népelem megjelenésével hozhatók összefüggésbe. ${ }^{35}$

Ezt megelőzően, illetve ezt követően sem tudjuk pontosan, milyen volt a férfiak hajviselete. A kevés írott forrás pántlikával összefogott varkocsokról emlékezik meg. Ezek száma akár több is lehetett, talán éppen három, ahogy azt a fent említett kőszobrok is ábrázolják, és elképzelhető, hogy varkocsdíszeket csak két copfra erősítettek. A késői időszakban a varkocsdíszek, de a különböző fésűk sem bukkannak fel a sírok mellékletei között. Ugyanakkor jogos az a feltevés, hogy a fésűk hiánya azzal is magyarázható, hogy ezek fából vagy más, a kárpát-medencei talajviszonyok között elenyésző anyagból készülhettek. ${ }^{36}$

\section{Szalu}

A balatonudvari temető 516. sírjából került elő egy vas szalu, amely az avar kori emlékanyagban szintén ritka leletnek számít. A sír a temető északi széléhez közel helyezkedett el (2. ábra).

Sírleírás: ÉÉNy-DDK-i tájolású (336) hanyatt fektetett, nyújtott helyzetű felnőtt sírja. A töredékes koponya a bal oldalára és a váz felé billent. Karcsontok szorosan a váz mellett („felhúzott vállak”), minden bizonnyal valamilyen anyagba tekerve helyezték a sírba. A gyenge megtartású csontok közül a csigolyák nagy része, a bordák és medencecsontok jó része felszívódott, jobb alkarcsontok egyikét a gyökerek a medencecsont felé elnyomták. Sírmélység 72 centiméter (9. ábra 1., 10. ábra).

Melléklet: A sír egyetlen melléklete a jobb lábszárcsontok mellett előkerült vas szalu volt, amely az egyik oldalán, élével a sírfal irányában helyezkedett el. Köpűjében és környékén fa nyomok maradtak meg. Ezek alapján úgy tűnik, hogy a szalut fa nyelével együtt, a lábszárcsontok alsó végéhez közel, keresztben helyezték el (9. ábra 2.).

A kovácsoltvas szalu köpűje enyhén ívelt, két oldalszárnya befelé hajlik, nem ér össze, ovális átmetszetű. Külső átmérője 4,9 centiméter, belső átmérője 4,2 centiméter. Kiszélesedő pengéje téglalap alakú, élben zárul, szélessége: 5,6 centiméter, hosszúsága: 4,5 centiméter, teljes hossza: 11,9 centiméter (10. ábra 1a-1b, 2a-2b.).

A fa megmunkálására, a felület egyengetésére szolgáló vas szerszámmal a legbehatóbban Kovács László foglalkozott. ${ }^{37} \mathrm{Az}$ általa összegyűjtött avar kori darabok száma azóta sem változott a publikált anyagokban. Veszprém megyében ez idáig egyetlen lelőhelyről, a jutasi avar temető 110. és 174. sírjából előkerült példányokat ismertük. ${ }^{38}$ Mindazok ellenére, hogy az udvari lelettel eggyel nőtt a lelőhelyek és a szaluk száma, összességében viszonylag ritkák az avar emlékanyagban.

33 CSALLÁNy 1960, 71.

34 Balogh 2013, 420, 441; Balogh 2016, 60-61.

A volt Szovjetunió és utódállamainak régészeti kutatásában a fésűkre vonatkozó önálló elemzés elég ritka. B. B. Ovcsinnyikova az altáj vidéki türkök anyaga alapján két típusba sorolta a fésűleleteket. Valójában, ahogy a magyar kutatás is, formai alapon választja szét a fésűket: széles, sok fésűfoggal rendelkező (I. típus, horizontálisan nyújtott) és hosszúkás, keskeny, kevés fésűfoggal rendelkező típusok (II. típus vertikálisan nyújtott) OvcsınnYıKova 1990, 64-65, puc. 33. fésűk válogatása. Úgy véli, hogy a velük együtt előkerülő tükrökkel együtt valamilyen rituális funkciójuk is lehetett. Általában tarsolyban őrzött darabokról van szó.

35 ANDRÁsI 1996-1997, 118.

36 Erre utal CsalLány 1943, 5; Részletesebben: Mesterházy 2012, 816-818.

37 KovÁCs 1983, 19-53. Utóbb Balogh Csilla foglalkozott a szalukkal. BALoGH 2013, 324-325; A 2. fázis jellemzése kapcsán: BALoGH 2016, 61-64.

38 Rhé - Fеттісн 1931, 24, 33, Taf. IV. 32, 38. 


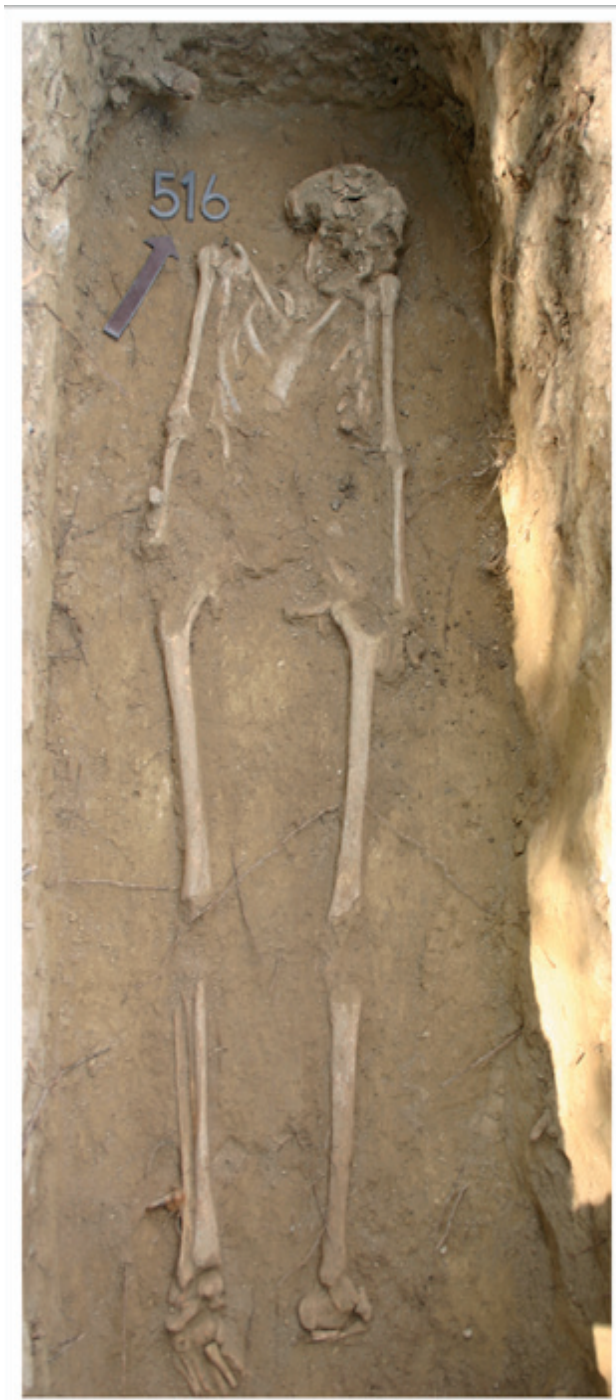

1.

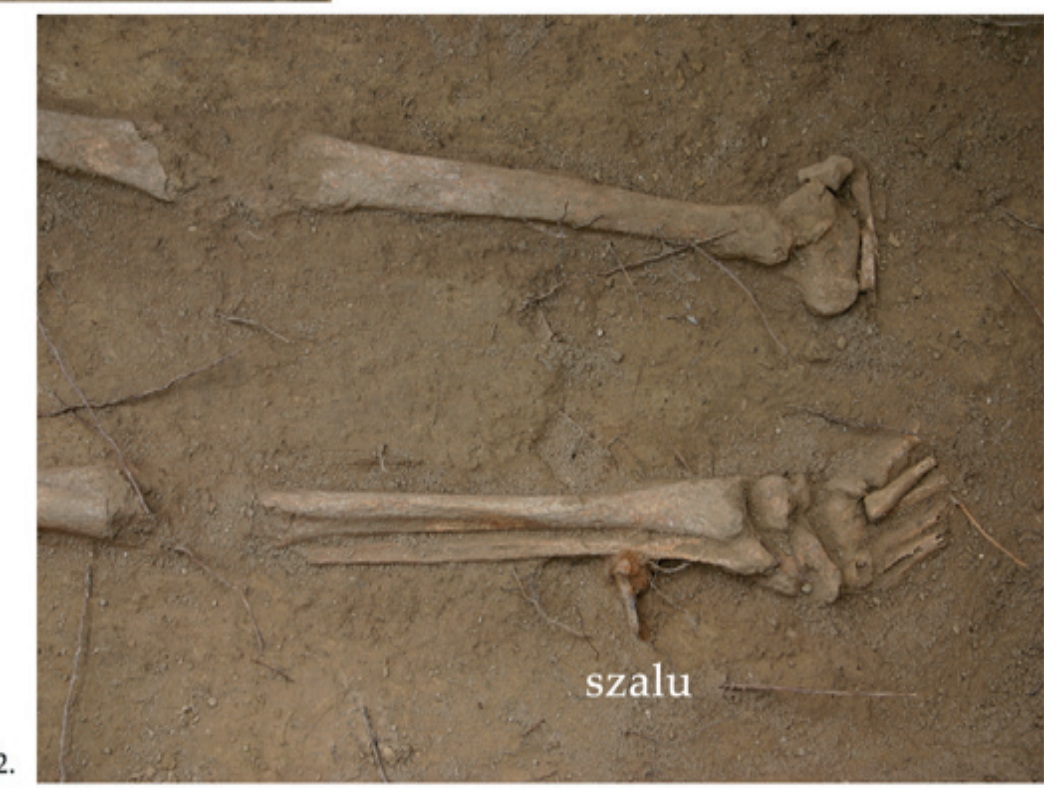

9. ábra. 1. Az 516. sír fotója; 2. A szalu elökerülésének helye 

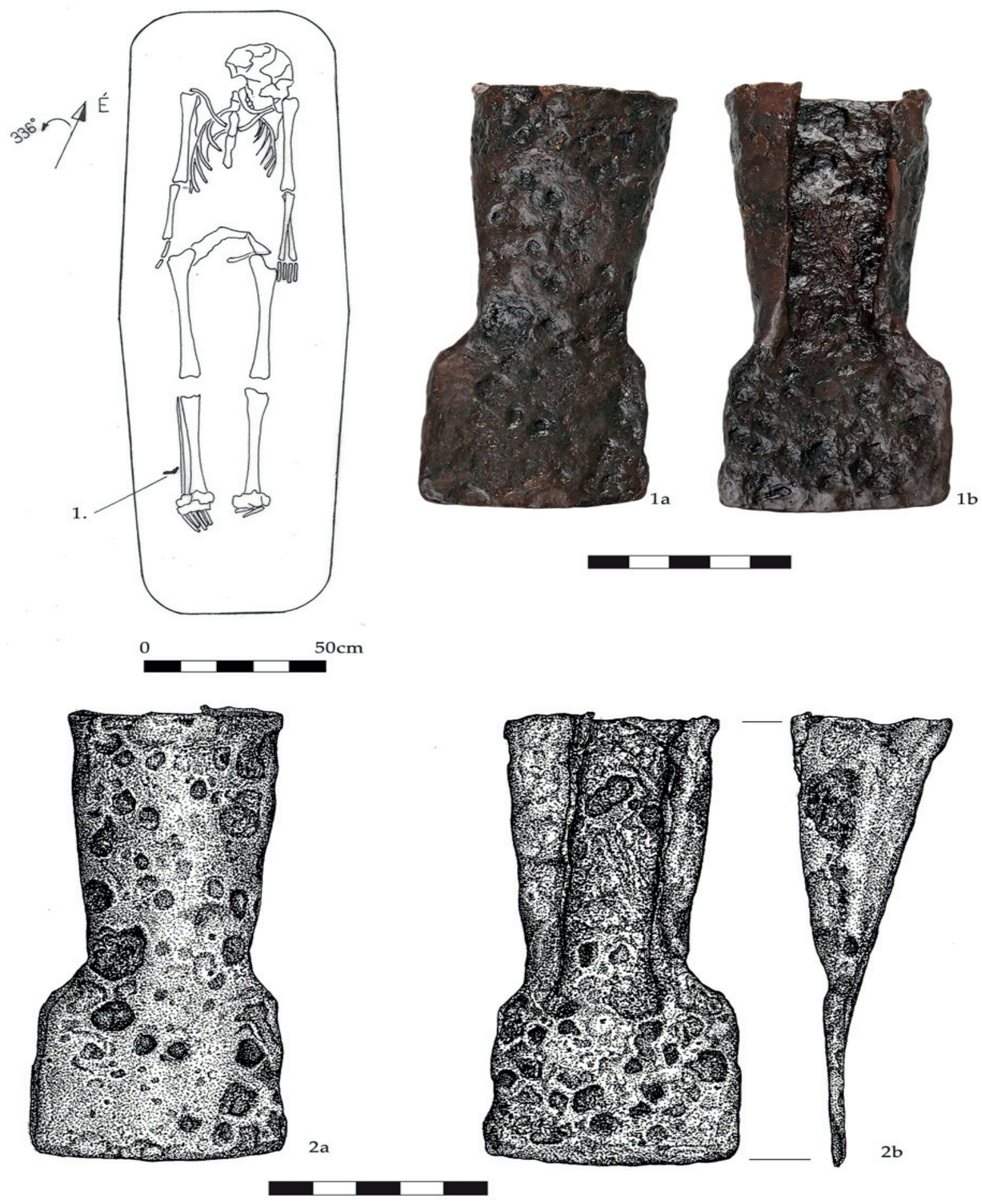

10. ábra. 1. Az 516. sír rajza;

1a-2b.A szalu fotója és rajza 
A népvándorlás korban, ahogy arra Kovács is utalt, ${ }^{39}$ hasonló munkaeszközre nincs bizonyíték. A római korban elsősorban a fa megmunkálására használt asciae, jelentősen eltér az avar kori daraboktól. Formai jellemzője a nyélre merőleges, kisebb-nagyobb mértékben lefelé ívelt vagy megtört penge. ${ }^{40}$ Nagy hasonlóságot mutat a kapákkal, illetve a mai napig is használt teknővájó eszközökkel.

A jellegzetes avar kori szalu - a varkocsfésűkhöz hasonlóan - az avarokkal jelent meg a Kárpát-medencében. Keleti eredetének bizonyítékait Erdélyi István, ${ }^{41}$ de elsősorban Kovács László gyüjtéséből ismerjük. ${ }^{42}$ Széles körben elterjedt, hosszú ideig használt munkaeszközröl van szó.

Legutóbb Ovcsennyikova foglalkozott hosszabban a szalukkal. ${ }^{43}$ Erős kritika alá vette Nyeszterov tipológiáját ${ }^{44}$ illetve az altáji türk leletek alapján összeállította saját tipológiáját. Az általa összeállított típusok szempontjai a szalu teste, pontosabban a köpűk elhelyezkedése, valamint a méretek voltak. Ezek alapján 3 csoportot különített el. A magyarországi avar darabokhoz az általa meghatározott 2. csoport áll közel, amelyet a nem erőteljesen kiugró vállak jellemeznek. A két altípus méreteiben tér el: a) hosszúság 9 centiméter, de a penge kissé szélesebb, mint a felső rész; b) hosszúság 12,5-13 centiméter, penge 5-7 centiméter között; köpú 4-4,5 centiméter között. Megállapítja, hogy ez a típus a keleti területeken nem jellemző, átmeneti típus. A párhuzamokat, analógiákat avar és honfoglaló anyagokban találta meg, azon népek körében, akikre egyébként sem jellemző maga az eszköz, azaz a szalu. ${ }^{45}$

A leletek metallográfiai vizsgálata alapján leírta, hogy ezek mindegyike acélból készült, kiváló minőségűek. Így nem csak a fa megmunkálására, de akár a fa kivágására is szolgálhattak. Funkciójúkkal kapcsolatban számos vélemény ismert, ${ }^{46} \mathrm{a}$ magyar szakirodalomban is számos néven szerepelnek. ${ }^{47}$ Bár nem zárható ki, hogy a szalut ásóként vagy akár a közelharc során fegyverként is használhatták, mégis elsődleges feladata a fa megmunkálása volt. Szinte kivétel nélkül férfi sírokból kerülnek elő. A fa megmunkálása mindig férfi munka volt, így az edények, a vadász és halász eszközök fa részeinek elkészítése, az asztalok, ládák, vagy éppen a nyílvesszők kifaragása stb., vagyis a mindennapok munkaeszközei voltak, sírba helyezésük még sem volt általános szokás. ${ }^{48}$

A keltező értékkel bíró mellékletet is tartalmazó szalus sírokat a kora avar korra, a 7. század első évtizedeire lehet keltezni, illetve a késő avar korban is megtalálhatók, elsősorban a felvidéki zsélyi (ma: Želovce, Szlovákia) és a dévényújfalui (ma: Devinská Nová Ves, Szlovákia) temetőkben, vagy a későbbi szláv temetőkben és telepeken is. ${ }^{49}$

A balatonudvari 516. sírból előkerült szalu Kovács László tipológiája szerint az 1. típusba tartozik, ${ }^{50}$ azaz tölcséresen keskenyülő, ellipszis alakú, nyitott köpü, szárnyai nem érnek össze, a köpúből ferdén kiugró vállak, trapéz alakú, kissé domborúan ívelt penge jellemzi. Mivel a sírban más melléklet nem volt, ezért a temetőn belüli elhelyezkedése alapján már a késői temetkezések közé sorolom.

A fentiekben leírt két sír leleteinek értékelése természetesen csupán az első lépés a temető feldolgozásának folyamatában. Ugyanakkor a ritkábbnak számító varkocsfésű és szalu leletek bemutatásával szerettük volna e két tárgytípusra ily módon is felhívni a figyelmet, további kutatások számára hozzáférhetővé tenni.

\section{Összefoglalás}

Balatonudvari település nyugati határában, a Fövenyes nevű részen, a 71-es számú út északi oldalán, egy viszonylag szúk völgyben több korszakon keresztül használt temető került elő 2002-ben. A leletmentés után 2009-2010, valamint 2013-ban folytak kisebb ásatások. A feltárt 583. sír (616 temetkezés) leletanyaga és a megfigyelt temetkezési szokások alapján kiderült, hogy a temető felső rétegeibe Ny-K-i tájolású 10-11. századi, alattuk É-D-i (ÉNy-DK-i) tájolású közép és késő avar sírok helyezkednek el.

Addig, amíg a 10-11. századi temetkezések a korábbiakat nem bolygatták meg, a késő avar közösség a korábbi közép avar sírokat (kivéve a legmélyebbeket) kirabolta, a csontokat a sírgödör két végébe dobta, újra felhasználva a már kiásott gödröt. Gyakran egy-egy sírba, rövid időn belül többen is temetkeztek, de nem ritka a kettős, többes temetkezés sem.

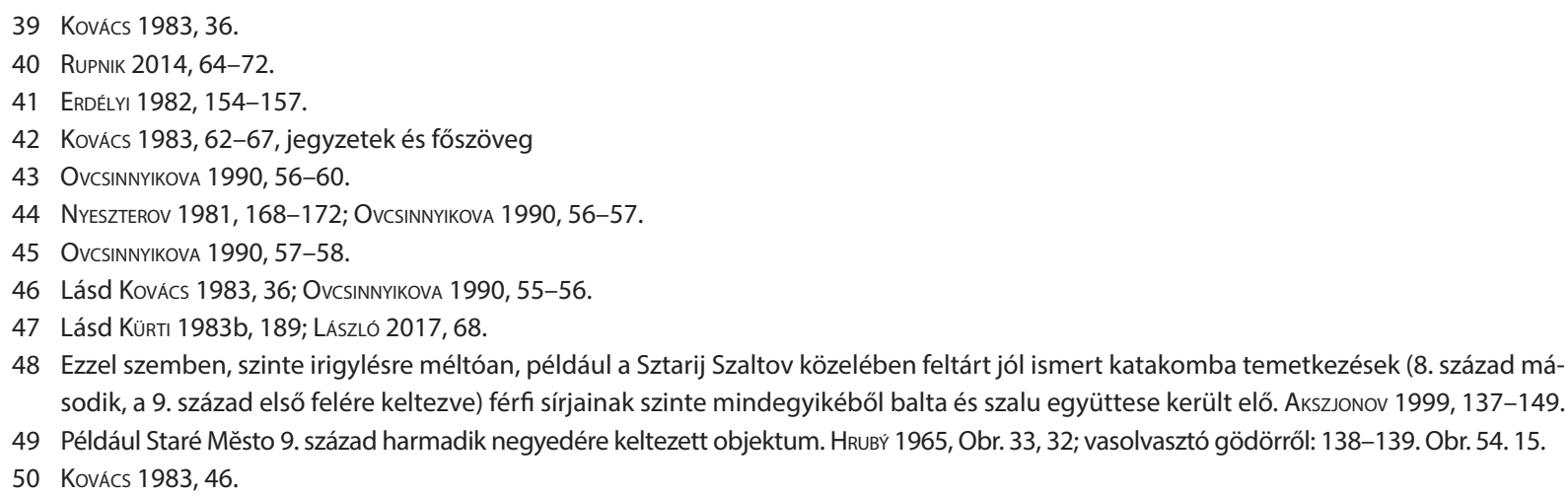


Összességében a balatonudvari-fövenyesi temető a Kárpát-medencei avar és 10-11. századi emlékanyagában különleges helyet foglal el, amely a két eltérő etnikumú, valamint a többrétegű közép- és késő avar temetkezéseknek köszönhető.

A tanulmány két olyan sír leleteit mutatja be, amelyek a szakirodalomban is ritkán bukkannak fel. A 309. sírból tarsolyban őrzött ún. pápai típusú csatja mellett kisebb méretű máltai kereszt alakú csat is napvilágot látott. Mindkettő már használaton kívüli, részben törött darabok. A kereszt alakú csat a hazai avar emlékanyagban ritka, hasonló csupán a Zamárdi-Réti földek avar temető 748. sírjából ismert. Mindkét csattípus a korai, bizánci eredetű darabok közé tartozik. Mellettük került elő az avarság keleti hagyatékának ritka darabja, egy csontból készült varkocsfésű. A hazai avar emlékanyagban csupán öt darabot ismertünk (Alattyán-Tulát 3 db; Szabadka-Mácskovics téglagyár/Subotica ciglana Macskovics; Deszk G. 2. sír). Mindazok ellenére, hogy a korábbi példányok a kora, illetve a közép avar időszak elejére keltezhetők, az udvari példány a feldolgozás jelen állása szerint már a közép avar kor derekán kerülhetett sírba.

Másik, a hazai avar anyagban szintén ritka lelet az 516. sírból előkerült vas szalu. A fésűhöz hasonlóan szintén az avarság keleti hagyatékának bizonyítéka. A fa megmunkálására szolgáló eszközök a kora avar korra keltezett sírokba gyakoriak, de használatuk még a késői időszakban is megfigyelhető. A balatonudvari példányt a késői időszakra keltezhetjük.

\title{
A braid comb and a woodworking adze from the Balatonudvari-Fövenyes cemetery
}

\author{
ÁGOTA S. PERÉMI
}

A burial ground used during successive periods was discovered on the western outskirts of Balatonudvari, in a relatively narrow valley located in an area known as Fövenyes on the northern side of Road 71. Following the initial rescue excavation, the investigation of the burial ground was continued in 2009-2010 and 2013 . The 583 graves contained 616 burials; the burial rite and the finds indicated that the cemetery's upper layer was made up of west to east oriented burials from the tenth-eleventh centuries, which overlay the north to south and north-west to south-east oriented middle and late Avar burials.

The tenth-eleventh century burials were not disturbed. The late Avar community had plundered the graves of the earlier middle Avar period (with the exception of the deepest ones) and re-used the grave pits after dumping the bones of the earlier burials in the two ends of the grave pits. Very often, several burials were deposited in the same grave pit, and neither were double and multiple burials infrequent. The BalatonudvariFövenyes cemetery occupies a special place in the Avar and tenth-eleventh century material record of the Carpathian Basin owing to the burials of the two different ethnic populations and the superimposed middle and late Avar burials.

Described and discussed here are the finds from two graves, which rarely appear in the archaeological literature. In addition to a Pápa-type buckle kept in a pouch, the grave inventory of Grave 309 included also a Maltese cross-shaped buckle. Both were broken pieces, unfit for use. Cross-shaped buckles are rare in the Avar material and a similar piece is only known from Grave 748 of the Avar cemetery at Zamárdi-Rétiföldek. Both buckle types can be assigned to the early types of Byzantine origin. The other find was a bone braid comb, rarely encountered artefact type attesting to the Avars' eastern heritage. No more than five other exemplars are known from the Avar material record (three from Alattyán-Tulát, one from Szabadka-Mácskovics brick factory/ Subotica ciglana Macskovics and one from Deszk G, Grave 2). While the other pieces can be assigned to the early Avar or to the onset of the middle Avar period, the comb from Balatonudvari was deposited in the grave well into the middle Avar period.

Another rare find in the Avar material is the iron woodworking adze from Grave 516, which, similarly to the comb, is part of the Avars' eastern heritage. Woodworking tools were frequently deposited in burials assigned to the early Avar period and their use is also attested during the late Avar period. The exemplar from Balatonudvari dates to the late period. 


\section{Irodalom}

АйБАБин 1999 Айбабин, А.И.:Этническая историяранневизантийского Крыма (Etnische Geschichte der frühbyzantischen Krim). Симферополь, 1999.

Aкszjonov 1999 АКСЕНОВ, В. С.: Старосалтовский катакомбный могильник. Vita antiqua N. 2. Київ, 1999.

ANDRÁsI 1996-1997 Andrási Júlia: Avar kori varkocsszorítók (Awarenzeitliche Zopfspangen). Archaeologiai Értesítő 123-124. 85-123.

BAKAY 1973 Bakay Kornél: Az avarok időrendjéről (Zur Chronologie Chronologie der Awarenzeit). Somogyi Múzeumok Közleményei 1.5-86.

BALOGH 2013 Balogh Csilla: A Duna-Tisza köze avar kori betelepülésének problémái. Doktori disszertáció. Kézirat, Budapest, 2013.

BALOGH 2016 Balogh Csilla: A Duna-Tisza köze avar kori betelepülése (The settlement of the avar population in the DanubeTisza interfluve region). Cumania 27. 55-74.

BÁRdos - GARAm 2009 Bárdos, Edith - Garam, Éva: Das awarenzeitliche Gräberfeld in Zamárdi-Rétiföldek. Teil I. Monumenta Avarorum Archaeologica Vol. 9. Budapest, 2009.

BIBó-BIGE 1901 Bibó-Bige György: Egy érdekes szabadkai sírlelet. Archaeologiai Értesítő 21. 431-432.

BıBó-BıGE 1902 Bibó-Bige György: Népvándorláskori takácseszközökről. Archaeologiai Értesítő 22. 408-410.

CSALLÁny 1943 Csallány Dezső: Az avarok varkocs-fésűje (Der Zopfkamm der Awaren). A Szegedi Városi Múzeum kiadványai II/4. 3-8.

CSALLÁny 1960 Csallány Dezső: Szabolcs-Szatmár megye avar leletei (Awarische Funde des Komitats Szabolcs-Szatmár). Jósa András Múzeum Évkönyve 1. 31-87.

Entwistle 2010 Entwistle, Chris: Notes on Selected Recent Acquisitions of Byzantine Jewellery at the British Museum. In: Chris Entwistle - Noël Adams (eds.): 'Intelligible Beauty.' Recent Research on Byzantine Jewellery. British Museum Research Publication Number 178. London, 2010. 20-32.

EsCHer 2014 Escher, Katalin: Plaques-boucles byzantines et apparentées de la période Vle-VIlle siècle trouvées en France. Revue archéologique de l'Est tome 63, n.186, 301-336.

ERDÉLYI 1982 Erdélyi István: Az avarság és Kelet a régészeti források tükrében. Budapest, 1982.

FJodorov-Davidov 1966 Г. А. ФЁДОРОВ-ДАВЫДОВ: КОЧЕВНИКИ ВОСТочНОЙ ЕВРОПЫ ПОД ВЛАСЬЮ ЗОЛОТООРДЫНСКИХ ХАНОВ. ТИПОЛОГИЯ И ДАТИРОВКА ИЗВАЯнИй. МосКвА, 1966.

Garam 2001 Garam, Éva: Funde byzantinischer Herkunft in der Awarenzeit vom ende des 6. bis zum ende des 7. Jahrhunderts. Monumenta Avarorum Archaeologica Vol. 5. Budapest, 2001.

HAMPEL 1905 Hampel, József: Alterthümer der frühen Mittelalters in Ungarn. I-III. Braunschweig, 1905.

HRUBÝ 1963 Hrubý, Vilém: Staré Město. Velkomoravský Velehrad. Monumenta Archaeologica. Acta Peraehistorica. Tomus XIV. Praha, 1963.

Jevtyunova 1952 Л. А. Евтюхова: Каменные изваяния Южной Сибири и Монголии. Материалы и исследования по археологии СССР. Том І. Москва, 1952. 72-120.

KIss 1998 Kiss Gábor: A késő avar kori állatfejes övforgók és akasztóveretek (Spätawarenzeitliche Gürtel- und Hängebeschläge mit Tierkopfverzierung). A Móra Ferenc Múzeum Évkönyve - Studia Archaeologica 4. 461-495.

KovÁcs 1983 Kovács László: A Hajdúböszörmény-Erdős tanyai honfoglaló sírlelet. Adatok az avar- és a honfoglalás kori szaluk elterjedéséhez (Der landnahmezeitliche ungarische Grabfund von Hajdúböszörmény-Erdős tanya. Angaben zur Verbreitung der Hohlbeile in der awaren- und landnahmezeit). A Hajdúsági Múzeum Évkönyve 5. $19-52$.

KovrIG 1963 Kovrig, Ilona: Das awarenzeitliche Gräberfeld von Alattyán. Archaeologia Hungarica 40. Budapest, 1963.

KöLtő - SZENTPÉTERI 2001 Költő László - Szentpéteri József: Gondolatok az avar-magyar asszimilációról temetőelemzések alapján (Gedanken über die awarisch-ungarische Assimilation aufgrund von Gräberfelderanalysen). In: Kiss Magdolna - Lengvári István (szerk.): „Együtt a Kárpát-medencében” A népvándorláskor fiatal kutatóinak VII. összejövetele. Pécs, 2001. 119-134.

KüRTI 1983a Kürti Béla: A szegedi táj története az avar korban. Doktori disszertáció. Kézirat, Szeged, 1983.

KüRTI 1983b Kürti Béla: Az avarok kora (567/568-805). In: Kristó Gyula (szerk.): Szeged története I/1. Szeged, 1983. $162-218$.

LÁszló 2017 László Gyula: A csákberény-orondpusztai avar kori temető (Csiky G., Éry K., Fancsalszky G., Fülöp Gy., Pásztor A., Rácz Zs., Szentpéteri J., Tomka P., Vida T., Vörös I. tanulmányaival). Szerk.: Garam Éva - Vida Tivadar - Koncz István - Skriba Péter - Szenthe Gergely - Szentpéteri József. A Szent István Király Múzeum Közleményei A sorozat 53. Székesfehérvár, 2017. 
Madgearu 2003 Madgearu, Alexandru: A Buckle of Pápa Type Found in the Early Byzantine Fortress Halmyris (Murighiol, Tulcea County). Peuce II. 15. 169-176.

Mesterházy 2012 Mesterházy Károly: Fésületlen dolgaink. Honfoglalás kori fésűk (Unsere ungekämmten Sachen. Landnahmezeitliche Kämme). In: Vida Tivadar (szerk.): Thesaurus Avarorum. Régészeti tanulmányok Garam Éva tiszteletére. Budapest, 2012. 813-822.

MogiLnyıкov 1981 Могильников, Р. А.: Сибирские древности VI-X вв. Тюрки. In. : Степи Еврази в эпоху средневековья. Археология СССР. Ред. С. А. Плетнева. Москва, 1981. 29-43.

Nyeszterov 1981 Нестеров, С. П.: Тесла древнетюрского времени в Южной Сибири. Военное дело древних племён Сибири и Центральной Азии. Ред. Ю. С. Худакова. Новосибирск, 1981. 168-172.

OtKa ZÁró Jelentés é.n. Bálint Csanád - Bíró Ádám - Bollók Ádám - Csiky Gergely - Langó Péter - Patay-Horváth András Takács Miklós - Türk Attila Antal: Bizánc közép-és kelet-európában. Régészeti és müvészettörténeti kutatások. https:// docplayer.hu/19176858-Bizanc-kozep-es-kelet-europaban-regeszeti-es-muveszettorteneti-kutatasok-otka-nk72636-zarojelentes.html

OvcsinnyIKova 1990 Овчинникова, В. В.: Тюркские древности Саяно-Алтая в VI-Х веках. Многофункциональные орудия, предметы быта и обихода. Свердловск, 1990.

S. PéŔMi 2003 S. Perémi Ágota: Avar kori leletek Kékkútról és a Balatonudvari-Fövenyes temető 99. sírja (Avar-age findings from Kékkút and grave no. 99. of the Balatonudvari-Fövenyes cemetry). Békés Megyei Múzeumok Közleményei 24-25. 271-294.

S. PeRÉMI 2005 S. Perémi Ágota: „avarok, honfoglalók...” Veszprém megye régészeti emlékei az avar kortól a 10-11. századig. Kiállításvezető. Veszprém, 2005.

S. PERÉMI 2014 S. Perémi Ágota: Balatonudvari-Fövenyes 195. avar kori sírja. In: Anders Alexandra - Balogh Csilla - Türk Attila: Avarok pusztái. Tanulmányok Lörinczy Gábor 60. születésnapjára. Opitz Archaeologica 6. Budapest, 2014. $287-311$.

PLEtneVA 1981 Плетнёва, С. А.: Кочевники восточноевропейских степей в X-XIII. вв. Печенеги, торки, половцы. In.: Степи Еврази в эпоху средневековья. Археология СССР. Ред. С. А. Плетнева. Москва, 1981. 213-222.

RHÉ - FEтTICH 1931 Rhé, Gyula - Fettich, Nándor: Jutas und Öskü. Zwei Gräberfelder aus der Völkerwanderungszeit in Ungarn. Skythika 4. Prag, 1931.

RupNIK 2014 Rupnik László: Római kori vasszerszámok Pannoniából. Doktori disszertáció. Kézirat, Budapest, 2014.

Schulze-DörRLAmm 2002 Schulze-Dörrlamm, Mechtild: Byzantinische Gürtelschnallen und Gürtelbeschläge im RömischGermanischen Zentralmuseum. Teil I. Die Schnallen ohne Beschläg, mit Laschenbeschläg und mit festem Beschläg des 5. bis 7. Jahrhunderts. Kataloge vor- und frühgeschichtlicher Altertümer Band 30-1. Mainz, 2002.

SCHULze-DörRLAmm 2009 Schulze-Dörrlamm, Mechthild: Byzantinische Gürtelschnallen und Gürtelbeschläge im RömischGermanischen Zentralmuseum. Teil II. Die Schnallen mit Scharnierbeschläg und die Schnallen mit angegossenem Riemendurchzug des 7. bis 10. Jahrhunderts. Kataloge vor- und frühgeschichlicher Altertümer. Band 30-2. Mainz, 2009.

UENZE 1966 Uenze, Syna: Die Schnallen mit Riemenschlaufe aus dem 6. und 7. Jahrhundert. Bayerische Vorgeschichtsblätter 31. 142-181.

VARSIK 1992 Varsik, Vladimir.: Byzantinische Gürtelschnallen im mittleren und unteren Donauraum im 6. und 7. Jahrhundert. - Byzantské pracky na strednom a dolnom Dunaji v 6.-7. stor. Slovenská archeológia 1992. 77-109 